\title{
Akulturasi Islam dan Budaya Masyarakat Lereng Merapi Yogyakarta: Sebuah Kajian Literatur
}

\author{
Arief Aulia Rahman \\ Staf Pengajar di IAIN Syekh Nurjati Cirebon \\ arief_aura18@yahoo.com
}

\begin{abstract}
The essay discusses how Islam was perceived and how it was developed in Java, within Lereng Merapi society in particular, and how Islam influenced local culture on one side and was influenced by local culture on the other. The author argues that there had been strong acculturation between Islam and local culture. He states that the spread of Islam in this society had taken long periods as Islam did not counter local culture. It, instead, penetrated with a persuasive approach by adopting local culture while preserving pristine Islamic doctrines.
\end{abstract}

\section{Abstrak}

Artikel ini mendiskusikan bagaimana Islam dipersepsikan dan dikembangkan di Jawa, khususnya di masyarakat Lereng Merapi, dan bagaimana Islam, pada satu sisi, berpengaruh terhadap budaya lokal dan, di sisi lain, dipengaruhi oleh budaya tersebut. Artikel ini membuktikan bahwa proses akulturasi antara Islam dan budaya lokal terjadi di masyarakat Lereng Merapi. Artikel ini juga membuktikan bahwa penyebaran Islam di masyarakat ini membutuhkan waktu yang cukup lama karena penyebarannya tidak mengabaikan budaya lokal yang sudah ada. Sebaliknya, Islam dipenetrasi menggunakan pendekatan persuasive dengan mengadopsi budaya local dan melestarikan doktrin Islam murni.

Kata Kunci: akulturasi, Islam, budaya, dan Merapi

\section{Pendahuluan}

Perkembangan Islam di Jawa tidak terlepas dari berbagai tradisi yang ada di daerah tersebut. Tradisi-tradisi yang ada berinteraksi dengan Islam yang datang kemudian di Jawa, ataupun sebaliknya, Islam berinteraksi dengan tradisi yang ada di Jawa. ${ }^{1}$ Masuknya Islam di Jawa membawa perubahan mendasar pada pola dan tatanan masyarakat, yang saat itu sebagian besar masih

\footnotetext{
${ }^{1}$ M. Bambang Pranowo, "Sinkretisme" dalam kuliah Agama dan Budaya Lokal, Sekolah Pascasarjana UIN Syarif Hidayatullah Jakarta, 21 Maret 2011.
} 
menganut agama Hindu. ${ }^{2}$ Realitas itu tampak dari tindakan sehari-hari yang dilakukan oleh masyarakat Jawa yang berbentuk kepercayaan terhadap dewadewa, kepada benda atau barang tertentu yang dianggap mempunyai kekuatan, ritual persembahan dan lain sebagainya. Kenyataan itu dapat dipahami bahwa metode pengembangan Islam saat itu -melalui para pedagang Gujarat dan menggunakan penyesuaian dengan budaya setempat-tidak mendapatkan banyak pertentangan dan cenderung berjalan lancar. Namun, apabila kita amati lebih menyeluruh, penyebaran Islam di Indonesia sebenarnya mengalami proses yang bertahap dan membutuhkan kurun waktu yang relatif lama. Kenyataan seperti itu dapat dilihat dalam beberapa situs peninggalan sejarah seperti penemuan batu nisan di Leran, Gresik, yang mengindikasikan bahwa Islam telah berkembang di daerah itu sekitar tahun 475 Hijriyah atau tahun 1082 Masehi. ${ }^{3}$ Proses penyebaran Islam yang membutuhkan waktu lama menjadi wajar, karena penyebaran misi Islam saat itu tidak dilakukan dengan "counter" budaya, tapi lebih menitikberatkan pada pendekatan persuasif melalui penyesuaian budaya setempat tanpa menggadaikan nilai-nilai Islam yang utuh.

Pemahaman yang cenderung berbeda muncul dari Mark R. Woodward, yang terkenal dengan karya "Islam Jawa"-nya. Woodward menyatakan bahwa Islam dan Jawa merupakan dua entitas yang berbeda dan tidak bisa disatukan. Islam dan Jawa adalah sebuah anatomi yang memberikan pemahaman bahwa Islam sebagai agama samawi (ciptaan Tuhan) berbeda dengan Jawa yang dipandang dengan romantis, arkaik dan penuh pesona. Penafsiran semacam itu memunculkan asumsi bahwa Islam Jawa tidak lebih dari agama rakyat yang mulai keluar dari nilai-nilai Islam itu sendiri. Hal ini kemudian diidentifikasi oleh Woodward sebagai pertautan Islam dan Jawa yang compatible.

Sebenarnya, hal ini adalah persoalan klasik Islam yang berusaha menyeimbangkan antara dimensi hukum dan dimensi mistik, antara wadah dan isi, antara lahir dan batin. Dalam hal ini Jawa dibaca sebagai varian yang wajar dalam Islam dan sama halnya dengan Islam India, Islam Persia, Islam Melayu dan seterusnya. ${ }^{4}$ Islam muncul di tengah-tengah masyarakat melalui pertemuannya dengan budaya lokal, yang mengartikan bahwa Islam tampil tidak dengan muka Islam seluruhnya melainkan ditambah dengan polesan

\footnotetext{
${ }^{2}$ Andrew menjelaskan tentang keberadaan agama Hindu di Jawa pada saat itu telah menjadi bagian yang tidak terlepas dari kehidupan masyarakat sehari-hari. Tradisi-tradisi yang muncul dari agama Hindu telah cukup mengakar dalam masyarakat. Lihal selengkapnya, Andrew Beatty, Varietes of Javanese Religion: an Anthropoligical Acount (Cambridge: Cambridge University Press, 1999), 211-214.

${ }^{3}$ Pradjarta Dirdjosanjoto, Memelihara Umat; Kiai Pesantren - Kiai Langgar di Jawa (Yogyakarta: LKiS, 1999), 31

${ }^{4}$ Mark R. Woodward, Islam Jawa; Kesalehan Normatif versus Kebatinan, (terj.), (Yogyakarta: LKiS, 1999), vi-vii.
} 
budaya yang ada. Hal itulah yang kemudian ditelisik lebih jauh oleh Snouck Hurgronje untuk mengungkap teori yang dikenal dengan teori Receptio. ${ }^{5}$ Maksud teori ini adalah Islam sebagai agama atau hukum normatif umat Islam dapat diterima di kalangan masyarakat Jawa jika tidak bertentangan dengan budaya Jawa.

Berkaitan dengan permasalahan antropologis tersebut, Clifford Geertz menyatakan bahwa jika pengkajian antropologis mengenai suatu agama menemukan kenyataan dalam kondisi stagnasi umum, maka akan menghasilkan lebih banyak varian-varian kecil tentang teoretis klasik. Kasus yang menarik dari sekelumit retorika itu adalah ibadat kepada leluhur untuk mendukung otoritas hukum generasi yang lebih tua dengan memaksimalkan tradisi-tradisi leluhur sebagai sarana penetapan identitas seksual dan status kedewasaan. Adanya pengelompokan ritual semacam itu mencerminkan oposisi-oposisi politis dan penentuan ruang-ruang mitos sebagai pijakan bagi pranata sosial dan rasionalisasi hak sosial yang istimewa. Kemudian, perlu dilakukan perluasan kajian antropologi sosial yang telah mapan untuk memahami esensi agama dan membaca hubungannya dengan skema budaya sekitarnya. Di masa lalu, fenomena itu menjadi diskusi Durkheim ketika mengkaji hakikat yang kudus; Weber saat membangun metodologi Verstehen; Freud saat menguji paralel antara ritus pribadi dan ritus kolektif; dan paparan Malinowski tentang perbedaan antara agama dan akal-sehat. ${ }^{6}$ Logika dan kerangka konseptual tersebut menjadi landasan berpikir penulis untuk menemukan hubungan yang kuat antara agama dan budaya lokal tertentu.

Batasan yang ditentukan oleh penulis adalah pada nilai-nilai esensial antara agama Islam dan budaya masyarakat Lereng Merapi, yang sekaligus menjadi permasalahan dalam tulisan ini yaitu: 1. Bagaimana interaksi antara tradisi masyarakat Lereng Merapi dan ajaran Islam? 2. Bagaimana pengaruh ajaran Islam terhadap tradisi masyarakat Lereng Merapi? dan 3. Bagaimana konstruksi Islam Jawa dalam ranah kearifan lokal? Untuk menjawab permasalahan tersebut, penulis mencoba membahas beberapa hal, termasuk konsep Kepercayaan Masyarakat Lereng Merapi, sejarah pertemuan antara Islam dan budaya Jawa, konstruksi Islam Jawa, pengaruh Islam Jawa terhadap kepercayaan masyarakat Lereng Merapi, dan sufisme serta kearifan lokal Masyarakat Lereng Merapi. Pertanyaan-pertanyaan tersebut akan dijawab

${ }^{5}$ Silahkan baca beberapa karangan Hurgronje yang berkaitan, seperti: Christiaan Snouck Hurgronje, Aceh, Rakyat, dan Adat Istiadatnya, (terj.) (Jakarta: INIS, 1996), Christiaan Snouck Hurgronje, Islam di Hindia Belanda, (terj.) (Jakarta: Bhratara Karya Aksara, 1983), cet. II, dan Snouck Hurgronje, Nasihat-nasihat C. Snouck Hurgronje semasa kepegawaiannya kepada Pemerintah Hindia Belanda, 1889-1936, Volume 1 (Jakarta: INIS, 1990). Baca juga, Clifford Geertz, The Religion of Java (Chicago: The University of Chicago Press, 1960), 123-126.

${ }^{6}$ Clifford Geertz, Kebudayaan dan Agama (terj.) (Yogyakarta: Kanisius, 1992), 2-3. 
dengan mengkaji berbagai literatur tentang konstruksi nilai-nilai Islam dan realitas budaya masyarakat Lereng Merapi. Dari pertanyaan itu pula akan dapat dipahami bagaimana Islam dan budaya lokal tersebut melakukan interaksi dan akomodasi serta realitas saling mempengaruhi satu sama lain.

\section{Konsep Kepercayaan Masyarakat Lereng Merapi}

Masyarakat Lereng Merapi memiliki kepercayaan yang bersifat sinkretik, atau sering dikenal dengan sinkretisme. ${ }^{7}$ Berdasarkan pemahaman kebahasaan, sinkretisme adalah suatu perpaduan atau keterpaduan. ${ }^{8}$ Sedangkan pemahaman menurut istilah adalah fenomena bercampurnya praktik-praktik dan kepercayaan-kepercayaan dari suatu agama dengan agama lainnya sehingga menciptakan tradisi yang baru dan berbeda, atau, dengan menggunakan istilah Bambang Pranowo, disebut dengan tradisi besar dan tradisi kecil. ${ }^{9}$ Konsep sinkretisme dibatasi pada sintesis keagamaan yang terbentuk setelah konsolidasi awal suatu agama. John L. Esposito menyebut sinkretisme sebagai sebuah penyimpangan dari inti agama induknya atau ungkapan ideal normatifnya. Namun, penganut aliran sinkretis ini menganggap walaupun sinkretisme telah keluar dari ide-ide dasar normatifnya, tetapi masih memelihara ciri-ciri agama induknya. Apabila diidentifikasi secara normatif, sinkretisme tidak dapat dibedakan dengan bid'ah. ${ }^{10}$ Konsep ini berkaitan erat dengan agama "normatif" dan standar keyakinan yang dianut oleh penganutnya ketika menentukan perbuatan yang boleh dan tidak boleh dilakukan. ${ }^{11}$ Dengan

${ }^{7}$ Lucas Sasongko Triyoga, Manusia Jawa dan Gunung Merapi: Persepsi dan Kepercayaannya (Yogyakarta: Gadjah Mada University Press, 1991), 8-10 dan 116-117. Lihat juga, Wisnu Minsarwati, Mitos Merapi dan Kearifan Ekologi: Menguak Bahasa Mitos dalam Kehidupan Masyarakat Jawa Pegunungan (Yogyakarta: Kreasi Wacana, 2002), 48. John Haba, "Bencana Alam dalam Perspektif Lokal dan Perspektif Kristiani," dalam Jurnal LIPI, Masyarakat Indonesia, Jilid XXXIV, No. 1 (2008), 29 709.

${ }^{8}$ Pius A Partanto dan M. Dahlan Al Barry, Kamus Ilmiah Populer (Surabaya: Arkola, 1994),

${ }^{9}$ Pranowo menguraikan kedua tradisi ini sebagai sepasang konsep yang diperkenalkan oleh Robert Redfield untuk menggambarkan bahwa dalam suatu peradaban terdapat dua macam tradisi yang disebut dengan great tradition dan little tradition. Great tradition adalah tradisi masyarakat yang suka berpikir dan dengan sendirinya mencakup jumlah orang yang relatif sedikit (the reflective few). Sedangkan little tradition adalah tradisi dari sebagian besar masyarakat yang menerima begitu saja tradisi dari generasi sebelumnya tanpa memikirkan secara mendalam tradisi yang dimilikinya. Lihat: Bambang Pranowo, "Runtuhnya Dikotomi Santri-Abangan: Refleksi Sosiologis Atas Perkembangan Islam di Jawa Pasca 1965" dalam Pidato Pengukuhan Guru Besar dalam IImu Sosiologi Agama pada Fakultas Ushuluddin IAIN Syarif Hidayatullah Jakarta (Jakarta: IAIN Syarif Hidayatullah Jakarta, 2001), 10-11.

${ }^{10}$ Nur Syam, Madzhab-madzhab Antropologi (Yogyakarta: LKiS, 2007), 106.

${ }^{11}$ John L. Esposito, Ensiklopedi Oxford Dunia Islam Modern, alih bahasa oleh Eva Y. N. dkk. (Bandung: Mizan, 2001), 176. 
kata lain, agama tetap menjadi sumber perilaku masyarakat. ${ }^{12}$ Percampuran antara konsepsi Islam dan tradisi yang ada di masyarakat Lereng Merapi, dengan merujuk pada teori Receptio, merupakan bentuk penerimaan tradisi Jawa terhadap ajaran Islam yang masuk dalam lingkungan masyarakat Lereng Merapi.

Dalam memaknai agama, kendala yang dihadapi adalah bahwa suatu agama telah mengambil bentuk yang beragam diantara suku-suku dan bangsabangsa yang ada di dunia ini. Bahkan, pada agama-agama lokal dan aliran kepercayaan, agama sangat dipengaruhi oleh unsur-unsur budaya. ${ }^{13}$ Keadaan itu berbeda apabila dikaitkan dengan sains dan filsafat, karena agama sangat menitikberatkan pada keterlibatan pribadi (self experience). Menurut istilah John Hick, agama merupakan suatu subyek yang sangat luas dan kompleks yang dapat dilihat dari berbagai perspektif hingga memunculkan bermacam teori tentang watak agama, seperti teori antropologi, sosiologi, psikologi, naturalis, dan teori keagamaan (wahyu), Sehubungan dengan itu, Titus mengartikan agama dalam dua klasifikasi yaitu: pertama, agama muncul dari kemauan manusia untuk menjalani dan menyempurnakan kehidupannya; kedua, agama berasal dari kesadaran manusia untuk mengakui keberadaan alam sekitarnya yang lebih sempurna dan memberikan kontribusi kepada kehidupan yang dijalaninya. ${ }^{14}$ Dua klasifikasi itu menunjukkan bahwa eksistensi agama banyak dipengaruhi oleh faktor kognitif, afektif, dan psikomotorik umat manusia untuk memaknai agama itu sendiri dan fungsinya dalam kehidupan manusia seluruhnya.

Pendefinisian agama tidak berhenti sampai di situ, menurut para ahli, agama adalah kepercayaan manusia terhadap kekuatan gaib yang mempunyai kekuatan dan pengaruh kepada manusia dalam melakukan tindakan-tindakan di dunia ini. Kepercayaan ini juga termasuk ditujukan kepada kekuatan-kekuatan lain dari luar dirinya yang sering memunculkan adanya fenomena alam. Contohnya adalah percaya kepada matahari, bulan, bintang, pepohonan, batu,

\footnotetext{
${ }^{12}$ Sayuti Thalib dan Hazairin mengukuhkan pendapat itu dengan mengeluarkan teori Receptie a Contrario, yang menyatakan bahwa hukum yang berlaku di masyarakat adalah hukum agamanya, dan hukum adat dapat diberlakukan asalkan tidak bertentangan dengan hukum Islam. Lihat: Sayuti Thalib, Receptio A Contrario (Jakarta: Academica, 1980), 5, dan Hazairin, Tujuh Serangkai tentang Hukum (Jakarta: Tintamas Indonesia, 1974). Bandingkan dengan: Ratno Lukito, "Law and Politics in Post- Independence Indonesia: A Case Study of Religious and Adat Courts" dalam Arskal Salim dan Azyumardi Azra (ed.), Shari'a and Politics in Modern Indonesia (Singapore: ISEAS, 2003), 27-28.

${ }^{13}$ Abdul Rachman Patji, Agama dan Pandangan Hidup: Kajian tentang Religi Lokal di Bali dan Lombok (Jakarta: LIPI, 2005), 116. Baca juga: Nur Syam, Islam Pesisir (Yogyakarta: LKiS, 2005), 22-24.

${ }^{14}$ Ali Sunarso dan Mochlasin Sofyan, Islam Doktrin dan Konteks; Studi Islam Komprehensif (Yogyakarta: Yayasan Ummul Qur'an, 2006), 25-26.
} 
dan lain-lain, yang sering disebut dengan dinamisme. ${ }^{15}$ Selain itu, terdapat kepercayaan yang meyakini adanya kekuatan yang berasal dari para leluhur atau nenek moyang mereka yang sudah meninggal dunia dapat memberikan keselamatan dan pertolongan kepada diri mereka, disebut dengan animisme. ${ }^{16}$

Kepercayaan-kepercayaan semacam itu sebenarnya tidak akan menghasilkan suatu sistem kepercayaan yang kokoh dan memuaskan karena tidak mempunyai perangkat-perangkat yang dapat membimbing manusia pada ketenangan hidup di dunia. Kenyataan itu tidak ayal membuat munculnya kepercayaan baru yang mempercayai banyak Tuhan (polytheism), dan secara perlahan mulai meninggalkan dinamisme dan animisme. ${ }^{17}$ Disadari atau tidak, manusia mempunyai suatu sifat yang tidak ada puasnya untuk mendapatkan sesuatu yang sesuai dengan kemauannya, termasuk dalam masalah agama. Terlepas dari kekuatan iman manusia itu sendiri dalam memegang dan menjalankan tuntutan ajaran agamanya, mereka akan selalu mencari kepuasan yang bersifat lahiriyah dan batiniyah. Dalam urusan agama pun mereka tidak segan untuk berpindah dari aliran satu ke aliran yang lain, atau dari agama satu ke agama yang lainnya untuk mendapatkan pengalaman baru.

Pemahaman umat Islam terhadap inti ajaran normatif selalu bervariasi sesuai dengan perkembangan waktu dan tempat dimana mereka berada. Gambaran ini memunculkan suatu pemahaman bahwa Islam dan nuansa yang berbau sinkretis akan memperlihatkan nilai-nilai dan keputusan. ${ }^{18}$ Artikulasi sinkretis sendiri tidak dipahami sama oleh seluruh umat Islam karena sebagian dari mereka mempunyai kategori definisi yang berbeda dengan sebagian yang lain. ${ }^{19}$ Kaitannya dengan hal itu, ada dua varian sinkretisme di dalam Islam modern: sinkretisme yang para pengikutnya mengklaim diri mereka sebagai Muslim dan mereka yang sepenuhnya menjaga jarak dari Islam normatif karena memeluk identitas di luar Islam. ${ }^{20}$ Keduanya dapat dikelompokkan sebagai berikut: kelompok pertama merupakan sinkretis dari sudut pandang ideal ortodoks yang mungkin ditolak oleh pelaku sinkretis tersebut, sedangkan

\footnotetext{
${ }^{15}$ Dinamisme adalah kepercayaan kepada suatu daya-kekuatan atau kekuasaan yang keramat dan tidak berpribadi, yang dianggap halus maupun berjasad seperti fluidum. A.G. Honig Jr. Ilmu Agama (terj.) (Jakarta: Gunung Mulia, 2005), Cet. Ke-11, 34.

${ }^{16}$ A.G. Honig Jr. Ilmu Agama, 53-54.

${ }^{17}$ Ali Sunarso dan Mochlasin Sofyan, Islam Doktrin, 26-27.

${ }^{18}$ Bandingkan dengan tulisan: J.J. Roy Burman, Hindu-Muslim Syincretic Shrines and Communities (New Delhi: A Mittal Publication, 2002), 8-9.

${ }^{19}$ Silahkan baca pergumulan antara Islam sinkretis dan Islam Puritan: Sutiyono, Benturan Budaya Islam: Puritan dan Sinkretis (Jakarta: Buku Kompas, 2010), 84-86, dan baca: Clifford Geertz, The Religion of Java, 153-155.

${ }^{20}$ Bandingkan dengan tulisan ini yang mencoba memahami dinamika sinkretisme dan dampaknya terhadap Islam: Carsten Colpe, "The Phenomenon of Syncretism and the Impact of Islam" dalam K. Kehl-Bodrogi, dkk. (ed.), Syncretistic Religious Communities in the Near East (Leiden: Brill, 1997), 35-37.
} 
kelompok yang kedua adalah diidentifikasi sebagai sinkretis. ${ }^{21}$ Memang, pada kenyataannya kedua kelompok tidak jarang berseteru untuk mendapatkan pengakuan bahwa kelompoknya yang paling benar dengan mengajukan argumen-argumen yang meyakinkan. Dari situ muncul pemaknaan kembali terhadap esensi Islam, yang dikatakan mengandung nilai-nilai universal dan tidak kaku dalam menyesuaikan dengan budaya yang ada di daerah tertentu. Apakah artikulasi itu masih relevan atau perlu adanya reinterpretasi di kemudian waktu untuk mendapatkan esensi Islam yang lebih relevan tanpa menghilangkan inti-inti normatifitasnya.

Beragamnya kelompok masyarakat menyebabkan setiap kelompok mempunyai warna yang berbeda satu sama lain, khususnya dalam menanggapi permasalahan seputar sinkretisme. Pertama adalah kelompok santri, yang terbagi dalam modernis dan konservatif, mempunyai karakter yang menjadi simbol bagi kelompoknya. Kelompok modernis lebih terfokus pada pemahaman tekstual, yang berdasarkan al-Qur'an dan Hadis. Sedangkan kelompok konservatif, selain memahami secara tekstual, juga memahami secara kontekstual. ${ }^{22}$ Contohnya adalah ketika menerima ritual slametan sebagai salah satu tindakan ibadah. Kedua adalah kelompok priyayi, yang memahami esensi agama dengan pemaknaan terhadap simbol-simbolnya dan mengikuti sektesekte tertentu. ${ }^{23}$ Ketiga adalah kelompok abangan, lebih banyak berkutat pada ritual agraris seperti slametan lingkaran kehidupan (rites of passage) mulai dari kandungan sampai mati, atau slametan desa (bersih desa) yang merupakan simbol kekokohan masyarakat petani dalam menjaga hubungan dunia kecil (jagad cilik) dan dunia besar (jagad gede), atau sering dikenal dengan istilah Manunggaling Kawula Gusti. ${ }^{24}$

Selain memberikan warna, ketiganya juga dapat dikatakan kelompokkelompok khusus dalam Islam Jawa berdasarkan karakter, struktur sosial, dan pola pikirnya terhadap Islam. ${ }^{25}$ Tentunya, dengan adanya klasifikasi itu

\footnotetext{
${ }^{21}$ John L. Esposito, Ensiklopedi Oxford, 176-177.

${ }^{22}$ Simbol yang terdapat dalam masing-masing kelompok dapat dilihat dari pola ritual yang dijalankan oleh santri. Baca selengkapnya di, Clifford Geertz, The Religion of Java, 215-218. Baca juga: M. Bambang Pranowo, Memahami Islam Jawa (Jakarta: Pustaka Alvabet dan LaKIP), 211 218 .

${ }^{23}$ Clifford Geertz, The Religion of Java, 231-234.

${ }^{24}$ Zainuddin Maliki, Agama Priyayi: Makna Agama di Tangan Elit Penguasa (Yogyakarta: Pustaka Marwa, 2004), 43-44.

${ }^{25}$ Dalam studi etnologis yang dilakukan Clifford Geertz mengatakan bahwa orang-orang Jawa tidak sungguh-sungguh memeluk Islam, hanya sebagian kecil saja yang dapat dikatakan penganut Islam sebenarnya yaitu komunitas kecil para pedagang dan hampir tidak ada sama sekali dalam lingkungan Keraton. Klasifikasi yang lebih jelasnya adalah kalangan Muslim (santri) sebagai kelompok yang berpedoman pada syari'ah-sentris. Sedangkan priyayi dan abangan merupakan Islam Jawa, dan bagi orang-orang kebatinan dikategorikan sebagai kejawen. Lihat, Mark R. Woodward, Islam Jawa, 2-3.
} 
memunculkan konsekuensi dan kompleksitas baru dalam sistem kemasyarakatan Jawa, yang terkenal dengan unggah-ungguh, sebagai manifestasi dari tindakan sosial keagamaan masyarakat Jawa.

\section{Sejarah Pertemuan antara Islam dan Budaya Jawa}

Pertemuan antara Islam dan budaya Jawa dipahami sebagai resepsi tradisi Jawa terhadap ajaran Islam. Relasi antara Islam dan budaya Jawa layaknya dua sisi mata uang yang tidak terpisahkan. Pada satu sisi, Islam hadir dan berkembang dipengaruhi oleh kultur atau budaya Jawa. Di sisi lain, budaya Jawa dipengaruhi oleh khazanah Islam yang begitu beragam. Pertemuan keduanya menunjukkan karakter yang khas berbentuk budaya yang sinkretis yaitu Islam Kejawen (agama Islam yang bercorak kejawaan). Pertemuan inilah dapat ditemukan pola "simbiosis mutualisme" antara Islam dan budaya Jawa. ${ }^{26}$ Pola itu bermakna bahwa antara Islam dan budaya Jawa mempunyai keterkaitan yang saling menguntungkan satu sama lain. Akomodasi budaya Jawa terhadap ajaran Islam memiliki asas kemanfaatan yang besar, dan begitupun sebaliknya.

Tradisi Jawa pada saat itu sangat kental dengan kepercayaan masyarakat Jawa, yaitu animisme dan dinamisme merupakan agama Jawa tertua yang mereka yakini. Pemujaan roh dan benda-benda tertentu yang dianggap mempunyai kekuatan dan dapat mendatangkan berbagai berkah mewarnai kehidupan beragama orang-orang Jawa. Selain kedua sumber kebatinan tersebut, mereka juga menganggap terdapat orang sakti dan memiliki perewangan yang datang dari kekuatan roh leluhur atau nenek moyang dan jimat dari benda-benda bertuah. Gambaran-gambaran ritual pemujaan roh yang dilakukan oleh masyarakat Jawa saat itu adalah slametan orang meninggal dengan berbagai macamnya, dari slametan surtanah (geblag), nelung dina, pitung dina, matangpuluh, nyatus, mendhak pisan, mendhak pindho, dan nyewu (nguwis-uwisi). Pemujaan lainnya adalah pemberian sesaji bagi dhanyang merkayan, sing mbaureksa, atau roh leluhur yang menjaga rumah atau tempat tinggal. ${ }^{27}$ Ritual slametan itu didasarkan pada hari atau penanggalan tertentu

\footnotetext{
${ }^{26}$ Dhanu Priyo Prabowo, Pengaruh Islam Dalam Karya-karya $R$. Ng. Ranggawarsita (Yogyakarta: Narasi, 2003), 9-10.

${ }^{27}$ Bagi orang Jawa, rumah atau tempat tinggal yang mereka tempati dipercayai terdapat rohroh halus yang menjaga tempat tersebut. Oleh karena itu mereka melakukan persembahan terlebih dahulu sebelum menempati tempat tersebut dan tidak meninggalkan tempat dalam waktu yang relatif lama tanpa ada yang menempati karena akan menjadi tempat yang angker. Mereka juga mempercayai tempat-tempat yang dianggap wingit (sakral), seperti pohon besar, belik, perempatan jalan, dan lainnya. Di tempat-tempat itu mereka menaruh sesaji yang diharapkan ada imbal balik untuk membantu kehidudannya. Lihat, Suwardi Endraswara, Mistik Kejawen; Sinkretisme, Simbolisme dan Sufisme dalam Budaya Spiritual Jawa (Yogyakarta: Narasi, 2004), 61-62.
} 
yang diyakini sebagai waktu yang penting dan sakral. Tujuannya adalah untuk mendoakan dan mendapatkan berkah dari orang yang meninggal tersebut.

Kepercayaan semacam itu sudah ada sejak zaman Hindu-Budha, kemudian terus berkembang dan menjadi suatu kepercayaan baru yaitu sinkretisme. ${ }^{28}$ Konsep kesatuan itu merupakan pembauran antara ajaran Jawadwipa dengan Hindu-Budha yang sangat sublim. Dalam hal ini, Jawadwipa bersifat lebih terbuka yang memudahkan kepercayaan Hindu-Budha untuk mengikutinya dan menjadikan sinkretisme diantaranya makin sulit dijauhkan. Hal yang paling menonjol dari pembauran itu adalah mistik kejawen yang menjadi titik sentral sinkretisme hingga sekarang. Konsep mistik ini sering disebut dengan paham panteisme atau manunggaling kawula-gusti. Dari paham itu muncul pembagian beberapa kelompok Islam seperti Islam puritan (santri), abangan (kejawen) yang menganut kebatinan, dan Islam priyayi. Nuansa sinkretis yang paling banyak muncul dalam bentuk karya-karya sastra berbentuk suluk, wirid, dan primbon. $^{29}$ Ketiga kelompok Islam tersebut mempunyai ritual dan pemahaman terhadap Islam yang berbeda. Bahkan, Geertz menegaskan perbedaan itu sebagai dikotomi santri, priyayi, dan abangan.

Keberadaan sinkretisme Jawa merupakan hasil pengolahan dan penyesuaian antara budaya lama dengan budaya Jawa, yang sering dikenal dengan istilah agama Jawa atau kejawen. Selain itu, sinkretisme dianggap sebagai tradisi rakyat yang dirintis oleh kaum abangan-meminjam istilah Geertz - yang makin kental dan sulit dibedakan mana budaya yang asli dan tidak. Oleh karena itu, banyak pengamat yang berbeda pendapat mengenai

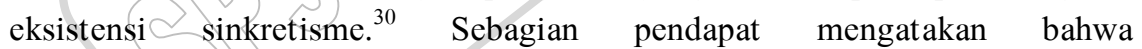
percampurbauran agama dan budaya itu menjadikan masing-masing kehilangan identitas dengan tidak menunjukkan nilai-nilai keasliannya. Pendapat seperti itu tampak sekali memposisikan sinkretisme dalam dataran yang negatif dan berdampak buruk dalam kehidupan umat beragama dan bermasyarakat sebab kerangka penafsiran yang dibuat adalah normativitas. Namun, sebagian yang lain menjelaskan bahwa sinkretisme itu hanyalah sebuah percampuran tanpa menghilangkan identitas dan nilai-nilai kemurniannya. ${ }^{31}$

Kerangka berpikir ini didasarkan pada penalaran historisitas, yang melihat sinkretis itu bukan pada ajaran atau doktrinnya saja tetapi juga pada akar

${ }^{28}$ Baca: J.J. Roy Burman, Hindu-Muslim Syincretic, 11-14.

${ }^{29}$ Suwardi Endraswara, Mistik Kejawen, 62-63.

${ }^{30}$ Suwardi Endraswara, Mistik Kejawen, 63-64.

${ }^{31}$ Kerangka berpikir normatif-historis ini merupakan konsep paradigmatis yang dijadikan suatu pendekatan agama dan budaya melalui dasar norma dan sejarah. Keduanya mempunyai cara pandang yang berbeda dan mempunyai hubungan yang kuat untuk memunculkan pendekat an agama yang bersifat teologis-normatif dan historis-empiris. Lebih jelas lagi, lihat, Amin Abdullah, Studi Agama; Normativitas atau Historisitas (Yogyakarta: Pustaka Pelajar, 2002), Cet. III, 12-18. 
sejarahnya. Berdasarkan sejarah terdahulu, dalam ritual mistik kejawen terdapat laku-laku yang mendapatkan pengaruh kuat dari Hindu-Budha yaitu laku-semedi. Termasuk juga pengaruh budaya seperti perhitungan saka dan pengembangan sastra keagamaan Hindu yaitu Ramayana dan Mahabarata ke dalam budaya istana yang merupakan wujud sinkretisme. ${ }^{32}$ Kedua sastra keagamaan tersebut sangat mewarnai budaya yang berkembang dalam lingkungan istana dan luar istana. Bahkan lebih dari itu, keduanya menjadi rujukan khusus sebagian besar masyarakat saat itu, tepatnya berkaitan dengan persoalan seputar keagamaan.

Masuknya Islam ke Jawa tidak terlalu banyak mengalami kendala karena Islam telah dipeluk oleh keraton sebagai basis untuk negara teokratik, sebagaimana yang dikemukakan oleh Hodgson dalam menjawab pertanyaan sejarah masuknya Islam ke Jawa. Sufisme (Islam mistik) membentuk inti kepercayaan negara (state cult) dan teori kerajawian yang tampak dari kerajaan-kerajaan Bali yang terindianisasi dan daratan Asia Selatan sebagai model utama agama rakyat. Hal itu juga tidak terlepas dari hubungan antara teks-teks keagamaan, agama rakyat, organisasi sosial, wacana sosial dan keagamaan. Usaha ini bertujuan untuk menyatukan teori neo-Tylorian, yang mendefinisikan agama sebagai suatu sistem penjelasan (explanatory system) dengan antropologi kognitif kontemporer dan "teori praktik" (practice theory). Melalui analisis ini akan mendapatkan suatu sistem pengetahuan aksiomatik, yang menyelesaikan secara teoretis, baik historis maupun etnografis. ${ }^{33}$ Dengan demikian, sufisme dalam Islam dapat dipahami secara integratif dan korelatif. Ketiga aspek bekerja secara sistematis untuk menunjukkan eksistensi sufisme Islam sebagai bentuk kesalehan sosial dan normatif.

Dalam memahami hal-hal keagamaan terdapat suatu substansi kuat yang menghubungkan antara ritual dan syari'ah (hukum Islam) serta bentuk-bentuk tingkah laku, yang sering disebut dengan "kesalehan normatif". Maksudnya adalah seperangkat tingkah laku yang didasarkan pada firman Allah melalui sabda Nabi Muhammad, bagi umat Islam. Doktrinnya adalah bahwa gnosis atau kesatuan dengan Allah bisa dicapai dengan jalan mistik atau sering dikenal dengan Sufisme yang bertujuan untuk membebaskan dari segala keinginan dan nafsu duniawi yang menghalangi manusia menyatu dengan Tuhannya. Lebih dari itu, persoalan yang berkembang adalah terkait penafsiran yang berbeda terhadap seperangkat aksioma budaya/keagamaan yang tunggal, diantaranya; pertama, keesaan Allah (tauhid); kedua, pembedaan Sufi antara makna batin

\footnotetext{
${ }^{32}$ Suwardi Endraswara, Mistik Kejawen, 64.

${ }^{33}$ Mark R. Woodward, Islam Jawa, 4-5. Kebudayaan yang berkembang di Keraton dan karakteristiknya sangat dipengarugi oleh sistem dan karakter pemimpin Keraton tersebut. Lebih jelasnya, lihat, Linus Suryadi AG., Nafas Budaya Yogya (Yogyakarta: Bentang, 1994), 42-45.
} 
dan zahir, ketiga, pandangan Alquran dan Sufi bahwa hubungan manusia dan Tuhan harus dipahami sebagai hubungan antara kawula dan Gusti; keempat, kesamaan mikrokosmos dan makrokosmos yang sama-sama dianut oleh tradisitradisi Sufi dan Hindu. ${ }^{34}$ Penafsiran-penafsiran tersebut disadari atau tidak berpengaruh pada pola tingkah laku manusia baik secara sosial maupun secara keagamaan, meskipun melalui cara memahami yang berbeda. Apabila ditelisik lebih jeli lagi, sebenarnya substansinya mempunyai kesamaan kuat dan dalam batasan yang masih menyatu.

Jika melihat kenyataan di masyarakat, orang Jawa mempercayai arus pengalaman subyektif sebagai sebuah mikrokosmos dari alam semesta yang sangat luas ini. Hal itu juga merupakan konsep Jawa yang meminjam istilah India, yang ditafsirkan secara khas: rasa. Rasa mempunyai dua arti pokok yaitu "perasaan" (feeling) dan "makna" (meaning). Rasa yang berarti "perasaan" (feeling) adalah salah satu dari pancaindra orang Jawa, yaitu: melihat, mendengar, berbicara, membaui, dan merasakan. Sedangkan rasa yang berarti "makna" (meaning) adalah penerapan pada kata-kata di dalam sebuah surat, puisi, atau dalam percakapan biasa untuk menunjukkan jenis ketidaklangsungan yang terkandung di antara baris-baris dan sugesti yang diyakini masyarakat Jawa. Dalam mengartikan rasa tersebut, orang Jawa lebih cenderung spekulatif dalam mengembangkan sebuah analisis fenomenologis yang sangat rumit mengenai pengalaman subyektif yang pernah dialaminya. Sebab pada dasarnya "perasaan" dan "makna" itu satu, dan pengalaman subyektif itu adalah kebenaran religius yang dialami secara subyektif, sebuah analisis empiris atas persepsi batiniah dan kenyataan lahiriah. ${ }^{35}$ Keduanya berpadu dalam suatu pengalaman yang melibatkan keaktifan nalar sosial dan nalar spiritual, yang diawali dengan spekulasi. Prinsip spekulasi itu bukan dalam artian mengartikan sesuatu dengan asal, tetapi lebih dikarenakan keterbatasan ruang-ruang empiris dalam menunjukkan kenyataan sebenarnya.

\section{Konstruksi Islam Jawa}

Bentuk Islam Jawa sangat identik dengan Islam sinkretik. Jika melihat perkembangan Islam-yang mempunyai pengaruh kuat terhadap eksistensi sinkretisme - di Asia Tenggara pada masa modern, maka ditemukan beberapa pengalaman yang terjadi tarik menarik antara konsesi-konsesi sinkretis terhadap budaya lokal dan perjuangan kaum reformis untuk menjaga kemurnian Islam. Yang lebih menarik lagi adalah tradisi estetika pribumi telah dipengaruhi dengan kuat oleh varian Asia Tenggara dari kisah Hindu Ramayana dan

\footnotetext{
${ }^{34}$ Linus Suryadi AG., Nafas Budaya, 6-9.

${ }^{35}$ Clifford Geertz, Kebudayaan dan Agama, 61-62 .
} 
Mahabharata, serta sistem politik yang berpusat pada raja dengan menampilkan kemegahan dan ritual seperti masyarakat India. ${ }^{36}$ Pendekatan Islam saat itu memberikan suatu kemudahan terhadap penganut agama Hindu untuk melakukan ritual-ritual Islam dan memeluknya secara perlahan. Di sisi lain, bagi sebagian Muslim yang saleh menolak dengan tegas model keyakinan seperti ini atau yang sering disebut dengan politeistik karena mencampuradukkan antara ajaran yang murni dan bukan murni.

Sebagian besar masyarakat Melayu melembagakan persyaratan Islam bagi pemberian sedekah, bukan sebagai amal bagi si miskin, tetapi sebagai ritus tahunan untuk menghormati para leluhur mereka. Bentuk ritual tersebut seperti festival makanan, tari-tarian dan hiburan yang lainnya. Tuhan dianggap sesuatu yang transenden dan tidak mudah untuk didekati, sehingga mereka lebih mempercayai roh para leluhur yang lebih bisa didekati dan menjadi dukungan moral tersendiri. Tradisi sinkretis ini merupakan jalan penolakan terhadap Islam, yang pada abad ke-19 masih terdapat daerah-daerah pemukiman Buddha (istilah yang sering digunakan sebagai agama pra-Islam), yang masih mempercayai ritual dan mitologi tertentu seperti Ajisaka, pahlawan kebudayaan dalam cerita rakyat Jawa yang hampir disamakan dengan Muhammad. Kedua tokoh tersebut ditegaskan telah mencapai kesepakatan bersama untuk menyandingkan Budha dan Islam hidup berdampingan. Model dualistik ini dipengaruhi oleh konsep-konsep keharmonisan kosmologi dari masa pra-Islam, keduanya diibaratkan seperti siang dan malam, laki-laki dan perempuan, atau langit dan bumi yang mempunyai hubungan erat. Walaupun pada masa gerakan pembaruan Islam gerakan harmoni sinkretis ini ditolak secara luas, namun unsur-unsur dan sekte-sekte kebatinan yang identik dengan nuansa sinkretis belum bisa lepas dari tradisi masyarakat, bahkan di sebagian kelas menengah perkotaan yang sudah banyak dipengaruhi pola-pola modernitas. ${ }^{37}$ Realitas itu menunjukkan bahwa sinkretisme sebenarnya menjelma dalam kehidupan masyarakat dalam bentuk kultural. Maksudnya adalah Islam sinkretik mendapatkan perlawanan besar dalam bentuk formal, tetapi resepsi terjadi dalam bentuk budaya yang berlaku di masyarakat.

Menurut William G. Doty, pernyataan-pernyataan mitologi itu menyampaikan suatu pengetahuan yang pasti, tetapi tidak terlalu banyak pengetahuan yang menjadikan laboratorium keilmuan sebagai pengetahuan

\footnotetext{
${ }^{36}$ Pada abad ke-19, sebagian besar orang Jawa dan Melayu memaknai dewa-dewa Hindu dalam Ramayana dan Mahabharata berdasarkan kosmologi sinkretis secara fleksibel. Bhatara guru, Brahmana, dan Iswara diperintahkan dari cakrawala Hindu dan dikonseptualisasikan ulang sebagai jin Muslim atau sebagai Nabi yang diutus sebelum Muhammad. Lihat, John L. Esposito, Ensiklopedi Oxford, 178.

${ }^{37}$ John L. Esposito, Ensiklopedi Oxford, 19. Lihat juga, Syed Muhammad Naquib Al-Attas, Islam dalam Sejarah dan Kebudayaan Melayu (Bandung: Mizan, 1990), 30-34.
} 
pengalaman komunal yang terbukti berguna dan memeliharanya. Mitos tersebut menunjukkan pemilahan antara persoalan psikologi dan pembelajaran adaptasional yang memungkinkan kita hidup lebih harmonis dengan alam dan kerangka budaya setempat, dan memungkinkan kita untuk mengemukakan suatu pendapat yang diperkaya dengan pemahaman dan daya jangkau yang luas. Di samping itu, untuk mewakili fakta dalam sebuah mitos adalah hal yang penting untuk mengakui bahwa alam dan budaya dapat diwakilkan dalam suatu ruang dialektika atau paradoks dan ruang pragmatis. ${ }^{38}$ Fakta memainkan suatu peran sebagai pembentuk mitos tersebut untuk dapat diterima logika dalam standar yang minimal. Keterwakilan fakta-fakta itu menggambarkan suatu mitos lebih jelas dan menempatkannya ke dalam ruang yang lebih terbuka untuk dimaknai dan dipahami.

Dalam konteks ini, sinkretisme dalam masyarakat Islam Jawa diyakini sebagai suatu yang sangat abstrak. Cara pandang metafisik diperlukan oleh mereka untuk melihat diri mereka sendiri dan lingkungan disekitarnya secara obyektif. Selain itu juga perlu ditelusuri lebih jauh dalam konteks konteks kultural, sosial dan politik tempat agama berada dan perhatian terhadap nonkeagamaan yang memengaruhi tradisi-tradisi lokal setempat. ${ }^{39}$ Kemudian yang perlu dipahami lebih lanjut adalah pembedaan kebudayaan dan agama Jawa, yang menegaskan unsur-unsur aksioma dalam masyarakat yang tunggal. Dengan menggunakan analisis struktural aksiomatik kita mendapatkan berbagai variasi karakteristik kepercayaan dan praktik keagamaan Jawa maupun lainnya. Pemahaman ini juga membawa kita pada proses-proses penafsiran dan kontruksi teks maupun cara-cara individu menegosiasikan makna dalam kehidupan sehari-hari. ${ }^{40}$ Unsur-unsur subyektifitas diperlukan sebagai keterlibatan individu dalam masyarakat untuk menghadirkan pola-pola yang lebih konstruktif dan menghilangkan kebakuan dalam memaknai teks-teks tertentu. Sebab disinilah terjadi tawar-menawar antara individu dan teks-teks yang membatasinya, sehingga pemaknaan terhadap teks berkembang dan menyesuaikan dengan kondisi yang ada dalam masyarakat.

Perseteruan yang tampak sekali terlihat adalah klaim terhadap penganut mistik kejawen. Secara ekstrim, mereka yang secara ideologi berseberangan menganggap laku spiritual mistik kejawen itu tergolong musyrik, termasuk

\footnotetext{
${ }^{38}$ William G. Doty, Mythography; The Study of Myths and Rituals, $2^{\text {nd }}$ Edition (Tuscaloosa; The University of Alabama Press, 2000), 94.

${ }^{39}$ Cara pandang metafisik yang masih dianut oleh masyarakat Jawa, misalnya mengungkap keberadaan Nyi Roro Kidul. Bagi mereka, Nyi Roro Kidul itu memang ada, dan bukan sekedar mitos. Selain keberadaannya, mereka juga mengakui adanya kekuatan mistis yang dimilikinya sehingga masyarakat mengkultuskan figurnya. Muhammad Solikhun, Kanjeng Ratu Kidul dalam Perspektif Islam Jawa (Yogyakarta: Narasi, 2009), 3-5.

${ }^{40}$ Mark R. Woodward, Islam Jawa, 36-42.
} 
laku yang sesat dan kurang berdalil. Anggapan semacam ini memang keterlaluan, sehingga Linus Suryadi menyatakan bahwa budaya religi komunitas budaya memang telah mapan sebagaimana ritual mistik yang tidak tergoyahkan oleh paham baru. Menariknya lagi ternyata pelaksanaan mistik kejawen di Yogyakarta masih tetap dipertahankan oleh pendukung setianya. Namun, ada pergeseran yang terjadi, sebelumnya ritual itu dilakukan secara individual sekarang dilaksanakan bersama-sama. ${ }^{41}$ Tujuan pergeseran itu bermaksud untuk mencari makna baru pada dasar-dasar kebudayaan Jawa dalam menghadapi modernitas dan globalisasi. Sehingga dampaknya adalah, jika sebelumnya mistik kejawen dilaksanakan di tempat yang sakral, sepi, sunyi, jauh dari manusia, maka kreator budaya ingin menampilkan sesuatu yang baru dan kebalikan dari tradisi sebelumnya.

Pada umumnya aliran atau paguyuban mistik kejawen berusaha mencari hakikat alam semesta, intisari kehidupan, dan hakikat Tuhan Dalam hal ini, ada empat golongan dalam aliran mistik kejawen, yaitu (1) golongan yang berdasarkan pada okultis, adalah golongan yang mengutamakan daya-daya gaib untuk melayani keperluan manusia, (2) golongan yang berpokok pada mistik, yang berusaha menyatukan jiwa manusia dengan Tuhan semasa hidup di dunia, (3) aliran theosofis, yang berupaya menembus sangkan paraning dumadi, (4) aliran yang bergerak pada etis, yang berhasrat pada budi luhur. Jelasnya, paguyuban-paguyuban tersebut mempunyai cara-cara pendekatan diri kepada Tuhan yang berbeda satu sama lain. Pada intinya, semua golongan itu memiliki dua hal inti yaitu proses sangkan paraning dumadi dan memayu hayuning bawana.

Konsep sangkan paraning dumadi memaparkan persoalan-persoalan yang berhubungan dengan ajaran Tuhan, asal-muasal jagad raya dan manusia sebagai jagad kecil, kelepasan dan kesempurnaan, dan lain sebagainya. Sedangkan memayu hayuning bawana berhubungan dengan usaha manusia untuk menjaga, melestarikan, dan mengembangkan dunia sebagai bekal bertemu dengan Tuhannya. ${ }^{42}$ Manusia diposisikan sebagai subyek yang menentukan karakter budaya sekitarnya, dan menjadi penentu berkembang atau tidaknya budaya tersebut. Budaya-budaya itu dengan aktif melibatkan peran akal dan tindakan manusia. Keberadaan akal dan tindakan manusia menciptakan cipta, karsa dan rasa yang timbul secara spontanitas dari dalam diri manusia. Dari sini juga muncul berbagai tipologi budaya dengan berbagai ciri kekhususannya.

Pada tindakan praktisnya, para penganut mistik kejawen melakukan bermacam aktivitas, yang diwarnai laku mistik kejawennya. Mereka sering

\footnotetext{
${ }^{41}$ Suwardi Endraswara, Mistik Kejawen, 14-15.

${ }^{42}$ Suwardi Endraswara, Mistik Kejawen, 17-18.
} 
melakukan laku tapa seperti tapa ngableng 3 hari dan tapa kungkum di beberapa tempat yang dianggap keramat. Misalnya adalah paguyuban Darma Sri Winahya kerap melakukan ritual di kali Bedog, makam Imogiri, makam Kadilangu, dan Kali Putih di daerah Turga Kali Urang. Para pelaku kejawen juga melakukan sesirik (mencegah) untuk membersihkan pekarangan rumah yang akan ditempati pertama kali supaya bersih dari gangguan roh halus. Ritual itu dilakukan dengan makan nasi dan garam, yang sering disebut mutih. Laku ini diharapkan mampu mengumpulkan kekuatan untuk mengusir dhemit, dhayang, dan jim setan periprayangan yang sering mengganggu manusia. Ritual lainnya adalah laku Mbisu yang disebut dengan Sonya Ratri Pamular Wening. Tradisi ini dilengkapi dengan saji-sajian dan upacara yang sakral.

Laku budaya spiritual ini tidak lain merupakan upaya pendekatan diri kepada Tuhan, agar kawula Ngayogyakarta Hadiningrat diberikan keselamatan. Maksudnya adalah baik laku Lampah Madya Ratri Kala Yuwana dan Sonya Ratri Pamular Wening adalah ritual yang bersifat kolektif dan patriotik. Keduanya bertujuan untuk ikut menegakkan sikap memayu hayuning bawana melalui olah batin. ${ }^{43}$ Berbagai ritual itu menunjukkan konstruksi Islam Jawa atau kejawen sangat dipengaruhi oleh pertemuan antara ajaran Islam dan budaya masyarakat Jawa, yang sebelumnya menganut agama Hindu. Berdasarkan ritual itu pula kemurnian ajaran Islam telah berbaur dengan tradisi masyarakat lokal, yang dapat dipahami terjadi akomodasi antara keduanya dan berbentuk simbiosis mutualisme.

\section{Pengaruh Islam Jawa terhadap Kepercayaan Masyarakat Lereng Merapi}

Apabila kita amati lebih mendalam, sebenarnya ada keterkaitan khusus antara mistik kejawen, kebatinan, dan kepercayaan. Ketiganya sama menggunakan laku spiritual dalam hidupnya. Walaupun pada dasarnya ketiganya mempunyai perbedaan dalam beberapa hal. Kepercayaan berarti suatu paham yang bersifat dogmatis yang terjalin dalam adat istiadat hidup sehari-hari dari berbagai suku bangsa yang mempercayai adat nenek moyang. Kebatinan didefinisikan sebagai bentuk kebaktian kepada Tuhan Yang Maha Esa menuju tercapainya budi luhur dan kesempurnaan hidup. Sedangkan mistik kejawen merupakan pelaku budaya yang berupaya untuk mendekatkan diri

\footnotetext{
${ }^{43}$ Dengan dasar itu, sebenarnya para penganut kejawen sangat menghargai dan percaya pada roh-roh para leluhur. Roh para leluhur itu harus dihormati dan didoakan supaya mendapatkan sawab (berkah) kepada penerusnya. Ritual itu juga bertujuan untuk mendapatkan wangsit yang merupakan bagian yang dipercayai dalam mistik kejawen. Wangsit (tanda-tanda gaib) ini diyakini sebagai suatu petunjuk terhadap sesuatu atau yang akan terjadi dan perlu ditindaklanjuti dengan laku spiritual. Tindak lanjut tersebut biasanya dilakukan pada saat Sekar Setaman dan direalisasikan dalam doa bersama. Lihat, Suwardi Endraswara, Mistik Kejawen, 19-22.
} 
kepada Tuhan. Dari ketiganya dapat diartikan bahwa mistik kejawen, kepercayaan, dan kebatinan adalah tiga sisi kultural yang saling melengkapi.

Mistik kejawen adalah perwujudan dari salah satu laku yang dilaksanakan oleh sebuah aliran kebatinan dan kepercayaan. Dapat diartikan juga, mistik merupakan bagian dari jurus kebatinan dalam praktik kultural. Masyarakat Jawa mendasarkan hidupnya pada ketentaraman batin, keselarasan dan keseimbangan (harmoni), yang dilandaskan oleh sikap menerima, sabar, awas eling (mawas diri), anoraga/andhap asor (rendah diri) dan prasaja (bersahaja). ${ }^{44}$ Prinsip-prinsip itu merupakan manifestasi dari ajaran keagamaan yang sudah ajarkan sebelumnya, yang kemudian pada langkah praksisnya diinterpretasikan menurut istilah dan kultur Jawa.

Gaya hidup kebatinan memperlihatkan suatu dimensi yang sarat dengan laku mistik yang merupakan bentukan dari kebudayaan Jawa, seperti kepercayaan mengenai ramalan terhadap kejadian-kejadian yang akan datang, penafsiran lambang-lambang dan kesaktian barang-barang keramat dan makam. Contohnya adalah sebagaian masyarakat Imogiri menganggap sakral makam raja-raja Mataram, rakyat Piyungan menganggap sakral makam Sunan Geseng di Jalasutra, rakyat Minggir Sleman mensakralkan makam Kyai Tunggulwulung, rakyat Gunung Kidul mensakralkan makam Ki Wisangjaya dalam tradisi Cing-cinggoling. Contoh lainnya adalah masyarakat lereng Merapi yang meyakini gunung Merapi sebagai makhluk hidup dan mempunyai kekuatan yang besar.

Beragamnya sifat-sifat kebatinan itu didasarkan pada: (1) batin, berasal dari bahasa Arab yang berarti perut, rasa mendalam, tersembunyi, rohani, dan asasi, (2) rasa yaitu sebuah pengalaman rohani subyektif, (3) keaslian, yaitu bangkitnya hasrat untuk mengembangkan kepribadian asli, (4) hubungan antarwarga, mereka bersatu karena terikat sebuah paguyuban yang memiliki kesamaan pandangan hidup yaitu ke arah manunggaling kawula-Gusti, (5) akhlak sosial, kebatinan adalah gerakan yang melawan demoralisasi, yang selalu mengedepankan etika sepi ing pamrih, (6) gaib, dalam kebatinan terdapat kepercayaan pada daya-daya gaib yang suprarasional, misalnya ilmu nujum, ilmu ngalamat, ilmu pertanda, zimat, tuah, dan sebagainya. Sifat-sifat itu sendiri mempunyai titik temu dengan pola pikir mistik kejawen, yaitu: (1) pola pikir etis, yaitu pemikiran mistis yang mengarahkan tercapainya manusia berbudi pekerti luhur atau manusia waskitha, yang dapat hidup harmonis antara makrokosmos dan mikrokosmos; (2) pola pikir kosmis, yaitu keinginan manusia

\footnotetext{
${ }^{44}$ Suwardi Endraswara, Mistik Kejawen, 29-30.

${ }^{45}$ Suwardi Endraswara, Mistik Kejawen, 30. Lihat juga, Hasan Muarif, Menemukan Peradaban: Jejak Arekologis dan Historis Islam Indonesia (Jakarta: Logos Wacana Ilmu, 1998), 98100.
} 
untuk melebur atau menyatu dengan alam semesta; (3) pola pantheistis, yaitu suatu paham antroposentris yang harus mengupayakan ke arah manunggaling kawula-Gusti. $^{46}$

Pengaruh budaya Jawa yang kuat dan melekat pada kehidupan masyarakat Lereng Merapi adalah prinsip falsafah hidup Jawa, yaitu suatu sikap hidup yang bertujuan untuk mencari kesempurnaan hidup melalui pangawikan (ngelmu) sangkan paraning dumadi dan manunggaling kawula-Gusti. Dalam hal ini, Pakubowono V, memberikan pesan yang berbau mistik dalam Serat Centini V: 279 yang isinya: "aywa lunga yen tan wruha, ingkang pinaranan ing purug, lawan sira aywa nadhah, yen tan wruha rasanipun, ywa nganggo-anggo siraku, yen tan wruh ranning busana, weruha atakon tuhu, bisane tetiron nyata." Kutipan ini memberikan pesan kepada mistikawan untuk menjalani hakikat hidup dengan berhati-hati. Pesan serupa juga disampaikan oleh 'guru mistik' dalam tembang dhandanggula ${ }^{47}$ sebagaimana berikut:

urip iku neng donya tan lami,

upamane jebeng menyang pasar,

tan langgeng neng pasar bae,

tan wurung nuli mantuk,

mri wismane sangkane nguni,

ing mengkopadha weruha,

yen asale sangkan paran duk ing nguni,

aja nganti kesasar.

Pesan mistik itu menganjurkan kepada manusia bahwa hidup di dunia tidak lama, ibarat manusia pergi ke pasar, akan segera kembali ke rumah asalnya tadi, karena itu jangan sampai ragu-ragu terhadap asal-usulnya, supaya tidak salah jalan. ${ }^{48}$ Pesan ini memberikan makna bahwa hidup didunia itu seperti kita singgah sementara, dan masih ada kehidupan yang lebih abadi setelah melewati jalannya kematian. Kehidupan di dunia adalah jalan untuk menentukan arah hidup selanjutnya, oleh karena itu kita diharuskan berhati-hati dalam bersikap dan mengambil suatu keputusan hidup yang berdampak pada kehidupan selanjutnya.

\footnotetext{
${ }^{46}$ Manunggaling kawula-Gusti merupakan perwujudan sikap manembah. Manembah adalah menghubungkan diri secara sadar, mendekat, menyatu, dan manungggal dengan Tuhan. Dunia mistik dilandasi paham theosofi atau disebut aliran kebatinan. Paham itu merupakan sebuah pengalaman, bukan ajaran. Suatu pengalaman yang benar-benar nyata, tidak terbatas bagi yang perah mengalaminya. Pengalaman ini, dalam mistik kejawen sering diibaratkan sebagai: curiga manjing warangka, warangka manjing curiga, ombak mungging jaladri, tapake kontul nglayang, kodhok ngemuli lenge, dan sebagainya. Lihat, Suwardi Endraswara, Mistik Kejawen, 31-32.

${ }^{47}$ Suwardi Endraswara, Mistik Kejawen, 33-34.

${ }^{48}$ Suwardi Endraswara, Mistik Kejawen, 34.
} 
Pada umumnya, masyarakat Yogyakarta banyak merujukkan persoalanpersoalan hidupnya pada petuah-petuah yang diberikan oleh Keraton, termasuk juga masyarakat Lereng Merapi. Keraton merupakan salah satu tempat yang sakral dan memiliki peran penting dalam membangun dan melestarikan budaya kejawen. Keraton Yogyakarta atau dulu dikenal dengan kerajaan Mataram mempunyai istilah khusus yaitu "masyarakat galaktis", yang berarti bahwa sebuah negara yang diorganisasikan sebagai suatu Mandala. Dalam negara itu terdapat empat penjaga tempat, yaitu Ratu Kidul, Sunan Merapi, Sunan Lawu dan Semar. Sunan Lawu dianggap sebagai raja terakhir Majapahit. Sunan Merapi adalah raja roh halus yang istananya berada di puncak Gunung Merapi, bagian utara kota. Semar adalah tokoh wayang yang disebut sebagai pembimbing spiritual Sultan. Mereka bersama-sama menetapkan batas-batas negara. Hubungan Sultan dengan para penjaga tersebut itu bersifat kontraktural, yang berarti ada proses saling member - berupa persembahanpersembahan dari Sultan-dan menerima - Sultan mendapatkan kesaktian dari mereka-. ${ }^{49}$ Sedangkan hubungan Sultan sendiri dengan masyarakat Lereng Merapi sendiri jelas sangat kuat dan tidak bisa dipisahkan dari pola budaya apapun. Masyarakat Merapi merupakan bagian dari wilayah yang 'dikuasai' oleh Keraton, sehingga tidak bisa lepas dari otoritas dan konstruk budaya Keraton.

Dalam hal ini, terdapat fenomena yang menarik di kalangan masyarakat Lereng Merapi. Fenomena tersebut berkaitan dengan figur tunggal yang kharismatik dan sempat tenar di belahan nusantara sekaligus, yaitu mbah Maridjan. Banyak orang menyebutnya sebagai juru kunci Gunung Merapi. Berdasarkan penelitian yang dilakukan oleh FX Rudi Gunawan, dijelaskan bahwa Mbah Maridjan adalah juru junci yang setia dan bertanggungjawab. ${ }^{50}$ Kedekatannya dengan Merapi telah membuka mata hatinya dan memberikan wangsit tersendiri. Merapi dianggap sebagai makhluk hidup dan harus dipahami dan diperlakukan sebagaimana makhluk hidup yang lain. Namun karena usia Merapi sudah sangat tua dan jauh sekali dengan usia kita, maka sudah selayaknya manusia menaruh hormat setinggi-tingginya pada Merapi sebagai makhluk hidup. Kepercayaan semacam itu pada kenyataannya membentuk kepercayaan tersendiri di kalangan masyarakat Merapi. Dapat dikatakan pula bahwa mereka mempercayai kekuatan dan nilai mistik besar yang terdapat di gunung Merapi. Hal itu juga merupakan cerminan nilai-nilai sinkretis yang dimiliki sebagian besar masyarakat Merapi.

\footnotetext{
${ }^{49}$ Mark R. Woodward, Islam Jawa, 293-294. 2006), 38 .

${ }^{50}$ FX Rudy Gunawan, Mbah Maridjan; Sang Presiden Gunung Merapi (Jakarta: Gagas Media,
} 
Salah satu ritual sinkretik yang dilakukan oleh masyarakat lereng Merapi adalah labuhan Merapi yang diselenggarakan setiap tanggal 30 Rejeb, menurut penanggalan Jawa. Ritual ini biasanya diikuti oleh orang-orang yang sudah lanjut usia dan para pecinta alam. Barang-barang (ube rampe) yang dibawa adalah milik Sri Sultan HB X, terdiri dari Semekan Bangun Tolak, Semekan Gadung, Semekan Gadung Mlati, Sinjang Kawung, Komplang, Sinjang Kawung Alit, Kampuh Poleng, Destar Daramuluk, dan Peningset Udaraga. Upacara Labuhan ini dimulai dengan membuka Uba Rampe yang dibawa dari Keraton Yogyakarta dan mendoakannya dengan memohon izin pada semua yang "lenggah" di Merapi (penunggu Gunung Merapi), diantaranya adalah Eyang Empu Romo, Eyang Empu Ramadi, Eyang Panembahan Prabu Jagad, dan para penunggu lainnya. ${ }^{51}$

Berdasarkan legenda yang dipercayai oleh masyarakat lereng Merapi, Gunung Merapi adalah sebuah keraton yang dibangun dengan hierarki mirip Keraton Yogyakarta yang terletak $20 \mathrm{~km}$ arah selatan dan istana Nyai Roro Kidul yang menguasai isi Laut Selatan Jawa. Cerita itu mengungkapkan bahwa Senopati, sebagai Sultan pertama dari kerajaan Mataram, pernah melakukan semedi di Gunung Merapi, yang menjadikan gunung itu bergetar dan mengeluarkan lidah-lidah api. Dalam keadaan seperti itu Roro Kidul keluar dari lautan dan menampakkan diri di depan Sultan dan menyatakan ingin menjadi kekasihnya, bahkan kekasih bagi sultan-sultan berikutnya, dengan syarat Senopati bersedia makan telur dunia yang diberikannya. Dari telur itu, yang ternyata tidak dimakan oleh Sultan karena khawatir akan merubah dirinya, terbentuklah sosok roh yang menyeramkan dan buruk rupa. Kemudian roh itu bersembunyi di dalam perut Gunung Merapi dan dikenal dengan Kyai Sapujagad.

Sejak itu, para Sultan secara turun temurun setiap berulang tahun membuat sesaji dengan mengirimkan makanan-makanan dan pakaian-pakaian kepada Kyai Sapujagad. Hal itu menjadi asal muasal adanya ritual Labuhan Merapi, ${ }^{52}$ yang sampai sekarang masih dijalani oleh Keraton dan sebagian masyarakat Merapi. Ritual itu merupakan tradisi yang harus dilakukan bagi masyarakat Lereng Merapi sebagai bentuk ketaatan kepada Tuhan mereka.

Penggalan cerita itu menunjukkan bahwa masyarakat Merapi masih mempercayai kekuatan benda yang dianggap keramat dan memiliki kekuatan dahsyat, seperti gunung Merapi. Nilai-nilai sinkretis yang terkandung didalamnya itu berupa ritual-ritual yang memadukan antara keyakinan terhadap doktrin Islam dan kepercayaan terhadap hal-hal yang berhubungan dengan

\footnotetext{
${ }^{51}$ FX Rudy Gunawan, Mbah Maridjan, 42-43.

${ }^{52}$ FX Rudy Gunawan, Mbah Maridjan, 44.
} 
mistik kejawen. Dalam kenyataannya, sebagian besar masyarakat Lereng Merapi beragama Islam. Namun, di sisi lain lain mereka tetap melakukan ritual yang tidak ada dalam ajaran Islam. Terlepas dari persoalan hitam-putih berdasarkan pandangan agama, lebih jelasnya adalah tindakan-tindakan yang mempunyai substansi sinkretisme masih sangat kental dalam lingkungan masyarakat Merapi.

\section{Sufisme dan Kearifan Lokal Masyarakat Lereng Merapi}

Islam yang berkembang di Indonesia dikenal dengan Islam mistik (sufi) yang memiliki karakter moderat dan akomodatif terhadap kebudayaan dan kepercayaan masyarakat tertentu. ${ }^{53}$ Dalam pandangan sejarah Islam, terdapat ruang besar terhadap istilah-istilah dari kepercayaan dan ritus-ritus non-Muslim dibandingkan para ulama. ${ }^{54}$ Neoplatonisme, mistisisme Persia dan Hindu semuanya memengaruhi perkembangan teori-teori mistik dan ritual-ritual banyak ordo sufi. Ajaran ini banyak berkembang di Asia Selatan, dimana kaum Sufi banyak mengadopsi praktik yogi Hindu dan menerjemahkan buku-buku Sansekerta ke dalam bahasa Arab dan Persia. Namun, ada beberapa aspek Hindu dan Budha yang dapat diterima oleh kalangan sufi. ${ }^{55}$ Aspek-aspek tersebut berhubungan dengan teori kelahiran kembali, sistem kasta dan penyangkalan Budha terhadap keberadaan Jiwa. Dari hal ini, dapat dikatakan bahwa secara umum kaum sufi Asia Selatan bersedia meneriman unsur-unsur Hindu dan Budha yang bersifat zahir (eksternal), tetapi menolak unsur-unsur yang hanya diartikulasikan sebagai batin (internal). Kenyataannya, mereka cenderung tidak menerima doktrin-doktrin kosmologis, sebagai lawan mitologis, dari agama-agama Asia Selatan. ${ }^{56}$ Struktur logika semacam itu juga yang berkembang di Asia tenggara, yang secara spesifik dibicarakan dalam tulisan ini adalah masyarakat Lereng Merapi. Pemahaman sufi memang berasal dari Asia Selatan, sehingga hampir tidak ada perbedaan substansial ketika dikaitkan dengan konteks kejawaan.

Tradisi-tradisi yang sudah dulu ada di Jawa seperti tradisi Hindu-Jawa yang masih bertahan hingga sekarang, terdapat dua hal penting yaitu tapa dan tradisi wayang. Dalam hal ini, terjadi banyak perdebatan yang melibatkan antara santri tradisional dan Muslim Kejawen bukan pada "kebenaran" formulasi Sufi mengenai doktrin tentang Allah, jiwa, dan jalan mistik,

\footnotetext{
${ }^{53}$ Sutiyono, Benturan Budaya, 72-73.

${ }^{54}$ Abdul Ghoffir Muhaimin, The Islamic Traditions of Cirebon: Ibadat and Adat among Javanese Muslims (Canberra: ANU E Press, 2006), 29-31.

${ }^{55}$ Hinduisme mengajarkan pada tradisi tunggalnya, yang menyatakan bahwa banyak ragam mistisisme yang dapat dikumpulkan dari penampakan-penampakan yang harus diinterpretasikan melawan teologi dogmatis. 5.

${ }^{56}$ Mark R. Woodward, Islam Jawa, 316-317.
} 
melainkan pada jalur eksoterik sebagai jalan kebenaran ini. Dari hal itu ada kesimpulan teoritis yang menyatakan bahwa perdebatan ini menunjukkan aspek multisimbolik sistem makna, pembatas yang bisa dikenakan pada proses simbolisasi dan masuknya makna literal (sebagai lawan simbolik) untuk kristalisasi keompok-kelompok sosial dan faksi-faksi politik-keagamaan. ${ }^{57}$ Simbol-simbol itu dengan jelas menampakkan keberadaan ajaran sufi dan Muslim Kejawen, yang merupakan ragam kebudayaan yang berkembang dalam masyarakat Jawa. Perbedaan itu sebenarnya terjadi juga dalam masyarakat Lereng Merapi, tetapi karena ikatan sosial yang lebih kuat hingga tidak sampai memunculkan pertentangan antara individu atau kelompok yang ada di masyarakat merapi.

Hubungan antara mistik kejawen yang dianut masyarakat Lereng Merapi dan tasawuf -yang mengembangkan ajaran-ajaran sufi-memang sangat dekat, hingga keduanya sering disejajarkan sebanding. Tasawuf merupakan bentuk mistik Islam, yang berupaya meluruskan pandangan manusia kepada Tuhan. Tasawuf itu sendiri merupakan bentuk peningkatan moral, untuk membersihkan batin dengan melibatkan peran batin tersebut dan intuitif manusia. Ajaran tasawuf itu bertujuan memberikan ketentraman rohani kepada umat manusia dan menekankan tindakan zuhud, yang menganjurkan hidup sederhana dan menjauhi kemewahan duniawi. Disamping itu, sasaran ajaran itu adalah mendekatkan diri kepada dzat al-Haqq (Tuhan). Keterkaitan dengan konteks Jawa, maka muncullah istilah sufisme Jawa, yang mengartikan adanya titik temu kepaduan antara paham sufistik dengan kejawen yang sama-sama menuju manunggal dengan Tuhan. Tindakan mistik ini juga berupaya menyatu dengan keberadaan Tuhan. ${ }^{58}$ Kesamaan tujuan dan sasaran keduanya adalah bentuk kesatuan makna untuk mendekatkan diri kepada Yang Maha Kuasa. Perbedaan yang dapat dilihat hanya pada cara-cara yang dilakukan masingmasing ajaran.

Titik temu antara tasawuf dan mistik kejawen yang dapat dipahami dengan jelas berdasarkan ritualnya yaitu sebagai upaya pendekatan diri kepada Tuhan. Jika tasawuf mengedepankan pemusatan batin melalui meditasi, mistik juga merupakan ajaran atau kepercayaan bahwa pengetahuan tentang hakikat Tuhan bisa didapatkan melalui meditasi atau kesadaran spiritual yang bebas dari campur tangan akal dan pancaindera. Tujuan utama mistik atau tasawuf adalah pencapaian makrifat yang tertinggi, melalui jalan tarekat. Tarekat pada dasarnya terdiri dari dua bagian, yaitu penyucian hati dari segala bentuk ikatan keduniawian yang dicapai melalui tujuh taraf peningkatan suasana batin yang

\footnotetext{
${ }^{57}$ Mark R. Woodward, Islam Jawa, 316.

${ }^{58}$ Suwardi Endraswara, Mistik Kejawen, 67-68.
} 
disebut dengan maqam, yaitu; taubat, wara (perwira, wirangi), zuhud, fakir, sabar, tawakal, dan rela. Maqam itu merupakan langkah penyucian ke arah pembinaan karakter budi luhur. ${ }^{59}$ Tradisi masyarakat Merapi memang tidak secara jelas menunjukkan pelaksanaan ritual tersebut karena kesadaran beragama mereka tidak terlalu mendalam. Sebagian besar dari mereka hanya menjalankan tradisi turun-temurun, yang mungkin mereka sendiri tidak begitu paham dasar yang digunakan seperti apa. Namun, dalam realisasinya mereka telah menampilkan sisi-sisi religiusnya seperti budaya unggah-ungguh, kerja keras, pasrah, hidup sederhana, peduli terhadap nasib tetangga, dan lainnya.

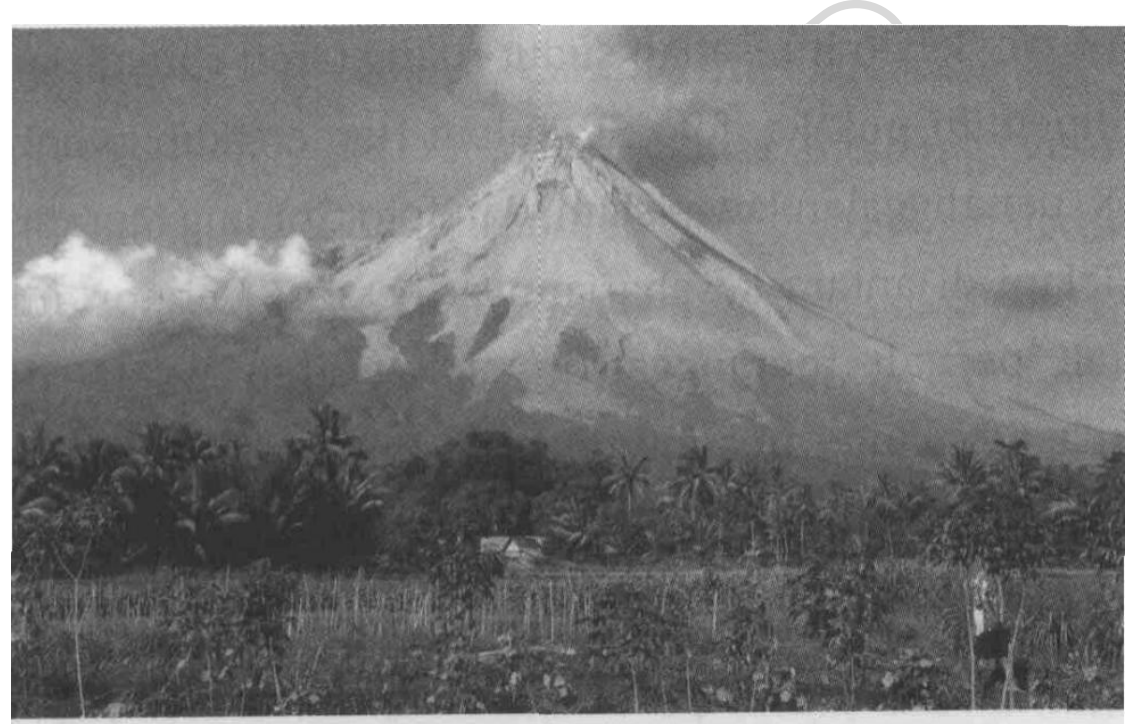

Puncak kearifan lokal. Dari kejauhan gunung Merapi tampak memberikan tanda-tanda kehidupannya. Di bawahnya terlihat persawahan dan pemukiman penduduk yang akrab dengan gunung tersebut.

Apabila kita amati dari sudut pandang sosial dan ekonomi terhadap perkembangan penduduk pegunungan-maksudnya adalah masyarakat Merapi-dalam dasawarsa 1970-an dan awal 1980-an, sebenarnya mereka sedang mengalami masalah identitas dan gejolak ekonomi. Sebutan mereka sebagai "orang gunung" (wong gunung) membedakan secara sosial dengan “orang dataran rendah" (wong ngare). Istilah regionalis ini digunakan untuk

${ }^{59}$ Titik temu keduanya didasarkan pemanfaatan Primbon Betal Jemur Adam Makna dan Kitab Mujarabat, yang diduga berasal dari buku tasawuf Ihya karya Al-Ghazali. Dalam kitab tersebut manusia digambarkan menjalankan: (1) neptuning dina dan pasaran, dihubungkan dengan rezeki manusia; (2) perhitungan menyembuhkan orang sakit; (3) mantra tolak bala, dan lain sebagainya. Lihat, Suwardi Endraswara, Mistik Kejawen, 68-69. 
menunjukkan perbedaan dalam masalah hierarki dan pola interaksi, karena mereka tidak begitu paham dengan istilah dalam ilmu sosial. ${ }^{60}$ Menurut pandangan orang gunung, orang dataran rendah bersikap kurang bersosialisasi karena jarang mengajak orang lain untuk mampir ke rumahnya, dan kalaupun menerima tamu mereka tidak bersikap luwes dan terlalu formal. Mereka enggan menyuguhkan makanan dan minuman kepada tamunya sambil berbincang lepas yang dapat mengakrabkan di antara mereka dan mencairkan suasana, tidak seperti yang dilakukan oleh orang gunung.

Cerminan sikap yang lebih jelas dari orang gunung adalah menekankan nilai-nilai yang tidak eksklusif dan kemerdekaan sosial. Dalam perbincangan, mereka berkata secara lugas dan tidak halus, yaitu dengan menggunakan bahasa ngoko yang tidak formal, dan bukan krama, yang merupakan bahasa Jawa "tinggi" dan memiliki muatas status sosial. Disamping itu, mereka mempunyai basis komunal yang kuat dan mempercayai bahwa semua penduduk berasal dari cikal bakal desa, serta mempunyai ketergantungan terhadap roh-roh penguasa tanah dan air. ${ }^{61}$ Unsur-unsur tingkah laku sinkretis yang ditunjukkan oleh mereka merupakan gambaran nyata sebuah kearifan lokal masyarakat Merapi. Mereka mempunyai karakter keberagamaan yang kuat dan kemurnian dalam membentuk tingkah laku mereka sendiri Secara tegas, mereka menjalankan prinsip hidup dan kepercayaan yang menjadi pedoman hidupnya, hingga mereka tidak mudah terpengaruh dengan budaya-budaya yang akan datang kemudian tanpa membawa identitas yang jelas.

\section{Penutup}

Berdasarkan pada pembahasan di atas, tulisan ini menyimpulkan bahwa pertama: interaksi antara tradisi masyarakat Lereng Merapi Yogyakarta dan ajaran Islam mempunyai makna sebagai akomodasi tradisi masyarakat Lereng Merapi Yogyakarta terhadap ajaran Islam. Dapat dipahami bahwa akomodasi tersebut berbentuk resepsi tradisi Lereng Merapi Yogyakarta atau Jawa terhadap ajaran Islam sebagaimana teori Snouck Hurgronje yaitu teori Receptie. Konstruksi ajaran Islam di Jawa menunjukkan adanya fenomena bercampurnya praktik-praktik beberapa keagamaan dan kepercayaankepercayaan seperti Islam, Hindu dan Budha sehingga menciptakan tradisi baru yaitu Islam Jawa (Islam kejawen). Dari hal itu dapat dipahami bahwa konsep

\footnotetext{
${ }^{60}$ Robert W. Hefner, Geger Tengger; Perubahan Sosial dan Perkelahian Politik, (ter.) (Yogyakarta: LkiS, 1999), 4-5. Dalam melihat fenomena ini, Clifford Gertz melakukan dua pendekatan untuk mengidentifikasi determinan-determinan sosial dari ideologi karena dia melihatnya hal itu tidak lepas dari sebuah kepentingan tertentu. Kedua pendekatan itu terdiri dari dua teori, yaitu teori kepentingan (the interest theory) dan teori ketegangan (the strain theory). Lihat, Clifford Geertz, Politik Kebudayaan, (ter.) (Yogyakarta: Kanisius, 1992), 12.

${ }^{61}$ Robert W. Hefner, Geger Tengger, 5-6.
} 
sinkretisme dibatasi pada sintesis keagamaan yang terbentuk setelah konsolidasi awal suatu agama. Para penganut aliran sinkretis menganggap bahwa mereka tetap memelihara ciri-ciri agama induknya, walaupun terdapat beberapa ajaran yang berbeda dengan ajaran Islam yang murni.

Kedua, pengaruh ajaran Islam terhadap tradisi masyarakat Lereng Merapi adalah kemunculan paham masyarakat setempat yang memadukan antara tradisi Jawa dan ajaran Islam, atau yang dikenal dengan Islam Jawa. Munculnya Islam Jawa dilatarbelakangi oleh berkembangnya ajaran Islam ke Jawa, dan menjadikan keraton sebagai basis penyebaran agama dan perubahan budaya. Kemudian mereka mengembangkan ajaran sufi yang membentuk inti kepercayaan negara (state cult) dan teori kerajawian yang mempunyai kemiripan dengan kerajaan-kerajaan di Bali yang terdoktrinasi dari agamaagama di Asia Selatan sebagai suatu model agama tersendiri. Doktrin-doktrin itu diperkuat dengan pola relasi yang terbentuk antara teks-teks keagamaan, agama rakyat, organisasi sosial, wacana sosial dan keagamaan. Kesalehan normatif yang ditonjolkan oleh masyarakat Jawa pada saat itu dengan menghubungkan antara ritual dan syari'ah (hukum Islam) dan bentuk-bentuk tingkah laku sebagai seperangkat tingkah laku yang transenden.

Ketiga, konstruksi Islam Jawa dalam ranah kearifan lokal berbentuk Islam mistik (sufi), yang mempertemukan ajaran tasawuf dan kearifan lokal masyarakat Lereng Merapi. Pertemuan tersebut merupakan kesamaan tujuan untuk mendekatkan diri pada Tuhan melalui caranya masing-masing. Peran tasawuf disini sebagai upaya meluruskan pandangan manusia kepada Tuhan, yang banyak menyimpang dari nilai-nilai keagamaan. Selain itu, tasawuf juga berupaya meningkatkan moral manusia, dan membersihkan keadaan lahir dan batin umat manusia. Sedangkan kearifan lokal merupakan pengembangan dari ajaran-ajaran tasawuf tersebut yang memadukan dengan budaya lokal yang telah ada sebelumnya. Berdasarkan ritual tersebut, tasawuf lebih menitikberatkan pada pemusatan batin melalui meditasi atau perenungan diri, sedangkan kearifan lokal menekankan pada ajaran atau kepercayaan bahwa pengetahuan tentang hakikat Tuhan dapat dicapai melalui meditasi atau kesadaran spiritual yang bebas dari campur tangan akal dan panca indera.

\section{Daftar Pustaka}

Abdullah, Amin. Studi Agama; Normativitas atau Historisitas, Cet. III. Yogyakarta: Pustaka Pelajar, 2002.

AG., Linus Suryadi. Nafas Budaya Yogya. Yogyakarta: Bentang, 1994.

Attas, Syed Muhammad Naquib Al-. Islam dalam Sejarah dan Kebudayaan Melayu. Bandung: Mizan, 1990. 
Beatty, Andrew. Varietes of Javanese Religion: An Anthropoligical Acount. Cambridge: Cambridge University Press, 1999.

Burman, J.J. Roy. Hindu-Muslim Syncretic Shrines and Communities. New Delhi: A Mittal Publication, 2002.

Colpe, Carsten. "The Phenomenon of Syncretism and the Impact of Islam" dalam K. Kehl-Bodrogi, dkk. (ed.). Syncretistic Religious Communities in the Near East. Leiden: Brill, 1997.

Dirdjosanjoto, Pradjarta. Memelihara Umat; Kiai Pesantren - Kiai Langgar di Jawa. Yogyakarta: LKiS, 1999.

Doty, William G. Mythography; the Study of Myths and Rituals, $2^{\text {nd }}$ Edition. Tuscaloosa: The University of Alabama Press, 2000.

Endraswara, Suwardi. Mistik Kejawen; Sinkretisme, Simbolisme dan Sufisme dalam Budaya Spiritual Jawa. Yogyakarta: Narasi, 2004.

Esposito, John L. Ensiklopedi Oxford Dunia Islam Modern. Alih bahasa oleh Eva Y. N. dkk. Bandung: Mizan, 2001.

Geertz, Clifford. Kebudayaan dan Agama, alih bahasa oleh Fransisco Budi Hardiman. Yogyakarta: Kanisius, 1992.

------. Politik Kebudayaan, (terj.). Yogyakarta: Kanisius, 1992.

-------. The Religion of Java. Chicago: The University of Chicago Press, 1960.

Gunawan, FX Rudy. Mbah Maridjan; Sang Presiden Gunung Merapi. Jakarta: Gagas Media, 2006.

Haba, John. "Bencana Alam dalam Perspektif Lokal dan Perspektif Kristiani." Jurnal LIPI, Masyarakat Indonesia, Jilid XXXIV, No. 1 (2008), 29.

Hazairin. Tujuh Serangkai tentang Hukum. Jakarta: Tintamas Indonesia, 1974.

Hefner, Robert W. Geger Tengger; Perubahan Sosial dan Perkelahian Politik, (terj.). Yogyakarta: LKiS, 1999.

Hurgronje, Christiaan Snouck. Aceh, Rakyat, dan Adat Istiadatnya, (terj.). Jakarta: INIS, 1996.

Islam di Hindia Belanda, (terj.). Jakarta: Bhratara Karya Aksara, 1983 , cet. II.

- Nasihat-nasihat C. Snouck Hurgronje semasa kepegawaiannya kepada Pemerintah Hindia Belanda, 1889-1936, Volume 1. Jakarta: INIS, 1990.

Jr., A.G. Honig. Ilmu Agama, (terj.). Jakarta: Gunung Mulia, 2005, Cet. Ke-11.

Lukito, Ratno. "Law and Politics in Post- Independence Indonesia: A Case Study of Religious and Adat Courts." Dalam Arskal Salim dan Azyumardi Azra (ed.). Shari'a and Politics in Modern Indonesia. Singapore: ISEAS, 2003.

Maliki, Zainuddin. Agama Priyayi: Makna Agama di Tangan Elit Penguasa. Yogyakarta: Pustaka Marwa, 2004. 
Minsarwati, Wisnu. Mitos Merapi dan Kearifan Ekologi: Menguak Bahasa Mitos dalam Kehidupan Masyarakat Jawa Pegunungan. Yogyakarta: Kreasi Wacana, 2002.

Muarif, Hasan. Menemukan Peradaban: Jejak Arkeologis dan Historis Islam Indonesia. Jakarta: Logos Wacana Ilmu, 1998.

Muhaimin, Abdul Ghoffir. The Islamic Traditions of Cirebon: Ibadat and Adat among Javanese Muslims. Canberra: ANU E Press, 2006.

Partanto, Pius A. dan M. Dahlan Al Barry Kamus Ilmiah Populer. Surabaya: Arkola, 1994.

Patji, Abdul Rachman. Agama dan Pandangan Hidup: Kajian tentang Religi Lokal di Bali dan Lombok. Jakarta: LIPI, 2005.

Prabowo, Dhanu Priyo. Pengaruh Islam Dalam Karya-karya $R . \quad N g$. Ranggawarsita. Yogyakarta: Narasi, 2003.

Pranowo, M. Bambang. "Runtuhnya Dikotomi Santri-Abangan: Refleksi Sosiologis Atas Perkembangan Islam di Jawa Pasca 1965" dalam Pidato Pengukuhan Guru Besar dalam Ilmu Sosiologi Agama pada Fakultas Ushuluddin IAIN Syarif Hidayatullah Jakarta. Jakarta: IAIN Syarif Hidayatullah Jakarta, 2001.

. "Sinkretisme" dalam kuliah Agama dan Budaya Lokal. Sekolah Pascasarjana UIN Syarif Hidayatullah Jakarta, 21 Maret 2011. . Memahami Islam Jawa. Jakarta: Pustaka Alvabet dan LaKIP.

Solikhun, Muhammad. Kanjeng Ratu Kidul dalam Perspektif Islam Jawa. Yogyakarta: Narasi, 2009.

Sunarso, Ali dan Mochlasin Sofyan. Islam Doktrin dan Konteks; Studi Islam Komprehensif. Yogyakarta: Yayasan Ummul Qur'an, 2006.

Sutiyono. Benturan Budaya Islam: Puritan dan Sinkretis. Jakarta: Buku Kompas, 2010.

Syam, Nur. Madzhab-madzhab Antropologi. Yogyakarta: LKiS, 2007.

Thalib, Sayuti. Receptio A Contrario. Jakarta: Academica, 1980.

Triyoga, Lucas Sasongko. Manusia Jawa dan Gunung Merapi: Persepsi dan Kepercayaannya. Yogyakarta: Gadjah Mada University Press, 1991.

Woodward, Mark R. Islam Jawa; Kesalehan Normatif versus Kebatinan, (terj.). Yogyakarta: LKiS, 1999. 